\title{
Metaphor and Materiality
}

\section{Dr. Aleksandra V. Jovanović}

University of Belgrade, Serbia

E-mail: andrej.radisic@gmail.com

\section{Dr. Nina Sirković}

University of Split, Croatia

E-mail: nsirkov@fesb.hr

\section{Doi:10.5901/mjss.2013.v4n9p158}

\begin{abstract}
To think about the material life of metaphors means to understand space as the projection of the inner self of their occupants. In order to occupy a foreign space one has to negotiate one's own vision of the world with the landscape one occupies. In the case of migrant writers metaphors of space are especially significant. This paper will discuss the novels Milenijum u Beogradu (Millennium in Belgrade) and Venecija (Venice) by Vladimir Pištalo, and the collection of short stories Infidelities: Stories of War and Lust by Josip Novakovich. Pištalo and Novakovich were born respectively in Bosnia and Croatia and now live and write in the USA and Canada. In Pištalo's literature places house memories and meditations about the Balkans and Mediterranean, while Novakovic explores a war-torn Balkan world which determines his protagonists' lives even when they migrate to a better and safer space where they have a fresh start. The aim of this paper is to explore the concept of "home" as the "original shell" (Bachelard) according to which every place in which we dwell has the "meaning of the universe". In addition, it will tackle Bhabha's vision of the home of migrant writers in the discursive space of their own literature.
\end{abstract}

Keywords: metaphor, space, dwelling, mapping, personal cartography, Carnival, mask, archetype, identity, quest

There are quite a number of critical studies which explore the connection between mental or cognitive mapping and literary craft. Among the first who systematically wrote about this topic was Gaston Baclhelard (1958). In his study The Poetics of Space Bachelard holds that to give an object a poetic space is to give it more space than it actually inhabits (Bachelard, 1994). More recently Peter Turchi, in his book The Maps of the Imagination: The Writer as Cartographer (2004), uses the term mental mapping as a metaphor for writing. "Writing and mapping... overlap, intermingle, and impersonate each other" (Turchi, 2004, p.12). Turchi writes that surveying, just as writing, includes selecting, omitting and inventing. In the influential study The Mirror of Herodotus: the Representation of the Other in the Writing of History (1988) Francoise Hartog puts the emphasis on surveying as a metaphorical equivalent of storytelling, thus exposing the connection between mapping and text:

The space of language is like a grid that can be applied to concrete space. Out of the jumble of dispersed, unapprehendable pieces, it constructs a puzzle in which the pieces fit together.... The narrator is thus a surveyor and, in a number of cases, a rhapsode, but he is also a bard, in that the inventory of the oikoumene, cannot fail to be an invention of the world (Hartog, 1988, p. 354).

The idea of space which is structured as a mental map has been especially interesting to trace in the works of migrant writers. In his essay "The World and the Home", Homi Bhabha examines the changed concepts of authenticity and home in the modern end-of-the-century world (Bhabha, 1992). In Bhabha's view the twentieth century's migrations and "cultural relocations" produced "deep stirrings of the world" in the private space of home. Bhabha claims that the "extra-territorial initiation" in the "house of fiction", brings various cultural voices into the original, authentic home. Accordingly, the discursive space of migration literature with the deep stirrings of cultural hybridity, presents, in Bhabha's words "my own corner in the world". Thus, the metaphors of home and authenticity mentally structure the spaces in which migrant authors dwell and meditate. Ultimately, they become materialized in the discursive space of their fiction.

The metaphors of home which resonate with the "discordant voices" of history shape the narrations of Vladimir Pištalo and Josip Novakovich. Vladimir Pištalo was born in Sarajevo and lived in former Yugoslavia until the last decade 
of the twentieth century. He now lives in the USA where he teaches history and writes novels and short fiction. Josip Novakovich is a Croatian writer who left former Yugoslavia at the end of the seventies and came to America as a transfer student, where he stayed for another thirty-five years. He now lives in Montreal, Canada. He writes in English, mostly short stories and essays. In his writing Novakovich often writes about the events from the former homeland, firstly Yugoslavia and later Croatia. His fiction is full of unexpected events, absurd and ironic situations, where war comrades become enemies and enemies become friends, hate vanishes in lust while his memories of homeland determine his present life in which the metaphors of home and the past map the characters' fate. The literary mapping of space in the fictions of Vladimir Pištalo and Josip Novakovich thus reinvent the world as a metaphorical representation of home in which their understanding of history and culture informs the images grounded in memory and presented as a collage of episodes.

Vladimir Pištalo's novel Milenijum u Beogradu (Millennium in Belgrade) reinvents the space of Belgrade, Serbia. Pištalo begins his novel by literally mapping the ground on which the edifice of the invented city will be built. The narration sets out with a legend about the idea of the city. According to the narrator, legend has it that the city was dreamt about at the "dawn of time". Namely, a man was fleeing from wild and outrageous centaurs who roamed the nearby mountains. He swam in the city rivers and fell asleep. Allegedly, he dreamt about a white and beautiful city - its temples and courts, its theatres and squares and its lovers and poets. Its angelic people strolled along streets in which "one would like to age". His passage foreboded the city space in its subsequent shape. He started from the foot of the nearby mountain Avala, then, followed the current of the rivers, the Sava and the Danube, right to their confluence beneath the city fortress Kalemegdan. This is where the dreamer reposed. When he finally opened his eyes an angel invited him into the City. Despite his longing, he could not find the courage to cross the city walls. He felt that he was too insignificant and small for the angelic city and he turned away from it. That is how he provoked divine rage: Gods cast a curse upon the City. This is the curse: "Let this place be a wound which cannot heal. Let dirty nails peel off its scab. Let the generations of sons never continue the deeds of their fathers. Let its inhabitants sneer at their own desires. This was the divine punishment to the man who turned away from his dream" (Pištalo, 2009, p 6).

The portrait of the city is painted along the axes of historical and "timeless time". The legend refers to eternal human fallibility and its tendency towards suffering. This human vulnerability marks the beginning of the historical existence of the city and situates the metaphor of the city, along with its beauty and damnation, at the intersections of the timeless with time. On the other hand the horrible account of the curse sets the stage for the subsequent pattern of events. Thus, the narrator foreshadows the character of the city depicting it as eternally torn between opposing metaphysical forces - to perish and to abide. Later in the text it will turn out that the dream has an important role as a macabre symbol of spiritual unity as each of its inhabitants over time take their share in it: "Last night I dreamt that I founded the city. It was whiter than bone. Whiter than chalk. It is curious that finally I didn't enter it, but I turned away from it and came back to the roaring wilderness" (Pištalo, 2009, p. 34). They dream without understanding the meaning of it.

After situating the city in its mythological context, Pištalo goes on to describe the fragments of its communal and individual history. Milan was born "many years after the dream about the city". However, as in the case of the legendary dreamer, his life depends on it. "Belgrade moved in its usual rhythm whose pulse beats in my blood" (Pištalo, 2009, p. 94).

The narration is woven out of several storylines that depict Milan's relationships with the people who "were Belgrade for me" (Pištalo, 2009, p. 26) revealing their mutual growing up, personal development, and the beginning of their ideological divergence. Milan's recollection of his adolescence in Belgrade links the life stories of several generations of inhabitants of Belgrade. Milan's ancestors, father and grandfather were famous artists while Milan was "still becoming... and has already failed to be what he really is" (Pištalo, 2009, p. 32). The metaphors of becoming and the futility of their quests loosely link several generations of fathers and sons who repeat the dream-curse, never to follow their desires, the sin for which they must be punished. Bane's grandfather was a Russian immigrant whose family actually returned to that country after several centuries as a voluntary exile. Milan's own grandfather was a surrealist artist and an "unbearable egoist who knew André Breton". They were followed by the generation of partisans of the Second World War - the city liberators. This was the generation of Milan's father, bohemian and poor, who left the country to become an acclaimed painter in Paris. His own father hated him because he was a better painter than he himself had ever been. The members of the third generation are the rock-an-roll kids of the '70s and ' $80 \mathrm{~s}$ - Milan and his friends. They were linked by the same aura of wanting and pursuing, never being able to settle. Three generations are connected by the same space and "curse", and their relations to their mutual friend and lover Olga.

After a night spent in her apartment, Milan learns that his father Andrija was the love of her life. Olga's ex-husband 
is the father of Milan's girl-friend. As a token of love Andrija painted Belgrade on the walls of one of the chambers of Olga's apartment. Andrija's wall painting captures all threads of the stories about the generations of Belgrade dreamers and travelers in a picture which depicts the harmony of the adverse worlds as "medieval ogres meet Renaissance peace."

"Andrija's Belgrade was the space of someone who grew up as nobody's dog, during the German occupation, stealing charcoal from German storehouses... I asked myself who the figures were [in his pictures] with the skinny limbs and ghostly bodies? ... Later... critics in Paris will call them 'metaphors of danger and spite'.... When Olga asked, Why do you paint such nastiness?, Andrija would answer, Your ex-husband... was a communist and he has ideals. He embellished the world. And what did he create? This, that is in my picture" (Pištalo, 2009, p.115).

As the metaphor of the painting constitutes a spatial representation of cyclical time, the city stories provide the narrative link between the events and Belgrade streets, parks, quays and squares. The spatial dimension of the narration is never far from the focus of the narrator as he punctuates his telling with remarks like, "the story is [italics are mine] a girl I loved, three friendships, one horrible war and many other wars, about the dissolution of the concept of the fatherland, about the continuous elopements and loss of support, the crashing of the world into its particles, and the longlost Byzantine technique of mosaic, about the mirror that can reflect the image of the soul and my attempt to see my reflection in others and the city I live in" (Pištalo, 2009, p. 40). The careless accounts of aimless hanging encode the feelings of loss and human smallness against the merciless force of history and power.

The grand historical narrations of the last decade of the millenium in Belgrade reside in the crevices of the personal accounts. They contribute the insecurities, fear and anxiety of Milan's generation to the portrait of Belgrade. Among Milan's friends, the ex-rock star Bane was forced to go to war. His life story merely continues the chain of yearnings, frustration and painful departures as it repeats the stories of the grandfather Teofil, father Andrija and Bane's own mother, years before.

The Devil entered into our lives in the last decade of the millennium. Generals ... were playing their endless games of billiards. In the military asylum Bane Janović was waiting for his "sentence". His bed was made of iron. He was lying among the bare walls. There was a wire behind the windows. While he was telling me this his cheeks were wet. 'I have sworn', snarled Bane through his tears, 'that I will leave the country if I stay alive'. (Pištalo, 2009, p. 89).

Vladimir Pištalo locates the joys and sorrows of the people within the city space of the past and present as the narration implies that the continuation of anguish of Belgrade inhabitants is a result of the spiritual cycle which is written in the Divine curse and embodied in the idea of circularity as a pattern of life in Belgrade. As Milan and his friends are, so were their fathers and grandfathers captured in the pattern of suffering, struggling, failing to understand, leaving and returning to the mythical space of the city.

A slightly different type of literary mapping shapes the narration in Vladimir Pištalo's novel Venecija (Venice). The reading of the space of Venice draws on mental mapping as much as on the symbolism of Venice. The portrait of Venice is set against the background of a broader picture of the Mediterranean which is painted as an abstract sum of history, legends, rituals and architecture. The narrator announces that the Mediterranean is:

\begin{abstract}
... the mumbling of prayers to the suffering Jesus and the passionate Priapus... [It is] yearning for bodies and sea.... Masks, clowns, deceivers, singers, wrestlers and gluttons. Prayers to the God whose name is Passion.... Flamenco and fado... Churches that are braided with mosques that are built into the walls of churches again... Gaudi's prayer that is a dance... Checked tablecloths and bills in glasses... Old women who look like embodiments of Fates.... Epileptic passion of quarrels... Revenge. The dream of mercy... Cat-like people with whiskers and sweat-sour smiles, the lovers of Circe, washed in foam, whose target is to reach the world's end. [The Mediterranean is] where a man and a snake drink from the same vessel at the funeral feast. When Sybils mumble the unfathomable destiny under cypresses. Mornings and tragedies of the Mediterranean. Peaceful corpses on sarcophaguses. Caper bushes that grow from tombs. Dogteeth in the shape of leeks that protrude from the mouth of Gorgon (Pištalo, 2011, p. 35).
\end{abstract}

However, the image of the Mediterranean also includes the anonymous inhabitants, travelers, and whoever has participated in its becoming and metamorphosis. As if the events and feelings are inscribed in the bodies of "all these lovers after swimming and drinking. The imaginary summer orgy..." (Pištalo, 2011, p. 35).

As the narrator intimates in this description of the Mediterranean, the city space of Venice is read simultaneously in terms of the archetypal symbolism and private encoding. He strays in the streets and squares of Venice inhabiting its space and filling it with the images of his own life - episodes from his youth, high-school adventures and stories about love. As he roams he dwells in the ideas and images of memory. 
Venice serves as a Grail figure - a metaphor of the treasured knowledge. "I needed that imaginary city as antipoison for the unreality of my life. I was beginning to search for it" (Pištalo, 2011, p. 14). The ambiguous refrain of the narration, "I was looking for her" could refer to the city, the goddess of love, Venus, or the narrator's own anima - all pointing to the quest archetype. The idea of formation is emphasized by numerous references in the text to the formative years of adolescence and episodes from high-school. Although the narrator repeats that "Venice cannot be described in terms of reason", the narration represents an attempt to search and know and to internalize the space through the process of telling.

"To inhabit is to experience the space by means of thoughts and dreams", says Bachelard, as the viewer begins to enter the space through a dialectical game of the I and non-I (1994, p 5). In other words, for Bachelard, as for Bakhtin, cognitive mapping stems from the dialogue of the Ego with its Otherness and ultimately gets engendered in language.

The constant dialogue between the Ego and the archetypes of the unconsciousness seem to be almost tactile (and spatial) within the space of the Venetian Carnival. The idea of a masked body is probably the most powerful spatial representation of the metaphorical "immensity". Pištalo exploits the archetypal, metaphorical, and spatial potentials of the Carnival. The psychological quest, searching and becoming is finally embodied in the archetypal thickness of the carnivalesque space and its potential to symbolically accommodate compressed time. Bakhtin also explains: "Carnival was the true feast of time, the feast of becoming, change and renewal" (Bakhtin, 1984, p. 10)... As Bakhtin has it "TThe body at the Carnival] is presented not in a private, egotistic form, severed from the other spheres of life, but as something universal, representing all the people... a people who are continually growing and renewed' (Bakhtin, 1984, p. 19).

In the spirit of constant movement and change, the notion of the carnival questions the boundaries between the present and past. The narration feeds upon the tension between the historical and mythical time in which "the masques around me spoke the language of the Jungian archetypes" (Pištalo, 2011, p. 153). The narrator confesses that "over time" he has been, "sometimes a hunter, sometimes prey, sometimes a fish, sometimes a bird, and both the archer and the one who has been killed" (Pištalo, 2011, p. 156). The flexibility of time engenders the sense of openness and unity in which 'the exalted and the lowly, the sacred and profane are levelled and are all drawn into the same dance' (Bakhtin, 1984, p. 160). The narrator acknowledges the blurring of identities in a metaphor which is one of the refrains of the narration, "We are You, you are we." (Pištalo, 2011, p. 7). Thus, carnival masks which hide the identity paradoxically open the Self to the vibes of the world's social, temporal and cultural immensity.

The pattern of life which is grounded in the idea of the Carnival, the Mediterranean and travelling transgresses each individual history. It is represented in the episode about the narrator's ancestor Trifun, or Tripko. Tripko was a sailor who came to Venice to trade his Montenegrin goods. He took to the Venetian spirit - its ritual and revelries. His amorous adventures, feasts, indulgences, transformations and secrets testify to the abstract orgy of many generations of Venetian travelers and merchants. His own history in Venice embodies the life stories of numerous Mediterranean salesmen and sailors who braided their own story with the story of Venice. Yielding to the human ambition to be immortalized in space, the narrator generously offers the space of his story: "Had that ancestor of mine rented a house or flat? Had he donated money to churches? Had he ever changed or built anything in the city? Had he put a single stone in the city's walls? If he hadn't, let his stone be this book" (Pištalo, 2011, p. 59).

The "voices of history" are also present in the mind of Josip Novakovich's characters. He has a flexible notion of borders, travels a lot and makes comparisons, showing great understanding of cross-cultural relations. His intimate writing style is full of humour, although his characters are often put in absurd situations caused by the unexpected war conditions.

In his essay "Shopping for a Better Country" Novakovich explains his relations towards exile, immigration and homeland. Having left the homeland of Yugoslavia as a transfer student in 1976, he was often considered as an exile from the Communist Block, but that was not true, because he could return to his homeland whenever he wanted. Although he finished his studies at Yale Divinity School and continued his education as a graduate student in the USA, he was not sure that he would not return home. During the war for independence he returned to Croatia to see what was happening there. The war affirmed that he could never feel like an American and that he could never reject his country. Although he has lived in America for thirty years and his children are Americans, the question of nationality is still open. Novakovich tries to find the answer to the question of whether he is a Croatian writer or American or Croatian-American. There was a period in his life when he wanted to be fully American and believed "that America was a cosmopolitan, multinational and transnational country" (Novakovich, 2012, p. 11). The problems of class still exist in all societies and the rich are getting richer and the poor even poorer all over the world and would, even if nations did not exist. Novakovich would feel those issues because he grew up with them and they were part of his psychology. He left one country for another and chose to become an American citizen and to write in English rather than in Croatian. After he had left 
Croatia, he found it easier to write about it from America and his being in America strengthened his feeling of being a Croat. He feels he has two nationalities, two identities, something he finds characteristic of America: dual identities are a part of most people's heritage. The notion of migration is constantly present in his thoughts:

\begin{abstract}
I think for me the essence of emigration, of being an émigré, is that I have not resolved the issue of national identity and that I never could. My coming to America took place too long ago: it has lost its freshness. I am tempted by the possibility or impossibility of another shift in identity. The shifting may be more important than the concrete choice of where to move and what national belonging to strive for. (...) being an émigré depends on breaking down the borders and definitions of national identities. I am exiled from easy definitions, from clear identity. Exiled from the exile, but not from migration, emigration and immigration. Who am I? It would be best if I could answer, Mensch, citizen of the world (Novakovich, 2012, p. 15).
\end{abstract}

Novakovich's collection of short stories Infidelities: Stories of War and Lust deals mainly with the contradictions of war. The territory of former Yugoslavia is suddenly divided into different countries, and people of different nationalities, who once lived together become enemies over the night. The author explores a war-torn Balkan world, the world which determines the protagonists' lives even when they migrate to a better and safer space where they have a fresh new start.

"Spleen" is a short story told by a female protagonist, an immigrant from Bosnia, half Serb, half Croat, who has been living in America for seven years. She has a good job at a bank and from the outside, she feels at ease in America. The news that a Bosnian family has moved to their neighbourhood suddenly brings memories from the past: namely, she was brutally attacked in her home during the war and one of the masked men tried to rape her. She grabbed the knife and stabbed him on his left side and somehow succeeded to escape, running naked through the cold November night. Even now sometimes she has nightmares and sleeps only with lights on. She begins dating Dragan, the neighbour's nephew, who seems familiar to her. She feels better among people from her homeland, she likes the smell of Turkish coffee and the taste of a smoker's kiss. All that reminds her of home, but at the same time she grows suspicious of the young man who is about the same age as her rapist. She feels lust for him, but when they make love he refuses to take off his shirt, what makes her even more suspicious. She has a nightmare, and in her dream she touches a brown scar on his left side under the ribs in the spleen area and it starts to bleed. The next day she hides a kitchen knife under the pillow. She is surprised to find out that hate and lust are not antonyms - she wants to make love with him, to see him naked because he might be her rapist, but she is surprised that at the same time she is so attracted to him. In the end, Dragan does not have a scar, and she finally starts enjoying him without second thoughts.

Mixed feelings of love and hate are also present in other stories such as "Snow Powder" and "Ribs". In "Snow Powder" the young school boy Mirko is disappointed with the school and the colleagues from his class, especially with the girl he admires and who has made a fool of him. At home his parents also seem not to understand him. One day, while he is skiing, he finds enemy soldiers on a hill who make him bring them plum brandy from the village. Instead of telling his parents that they are surrounded by Serbs who would bomb the village, he tries to steal the brandy, but is caught by his father who hits him severely. He decides to join the Serbs, goes to their bunker and watches them bomb the village. In his childish revenge he wants to watch the school blow up along with all the teachers and pupils who have teased him. As he looks at the smoke in the valley, that grows higher and wider, he is happy. Child warriors, drunken soldiers and love of destruction are parts of every war.

An absurd situation also appears in the short story "Ribs", where Mira, whose Croat husband is lost in the war, tries to prevent her son from being enlisted. She gets an offer from the director of the recruitment centre to sleep with him and as a favour he will spare her son from being sent to war. At first she is determined to reject him, but after a while, she decides to accept the offer and sacrifice herself. When she is left alone with him in a room, she is not sure if there will be any sacrifice: she has a fear of him, but at the same time she is attracted to him. She actually wants sex, but it turns out that he loses his desire for her. He participated in a Bosnian war massacre together with Mira's husband. They were forced by the officer to go from door to door and kill Bosnian women and children. As Mira's husband protested against the killing, he was brutally shot by an officer. He was probably buried with the Muslims. Nothing could be done about pulling his body out because the Croatian army had not been there officially and the whole story might end at the Hague court. Mira felt helpless. She had not got along with her husband, he was a nuisance, but now that he is dead, she feels unrest, because he has not been buried properly. She continues her affair with the director, but begins hallucinating, but when her late husband appears in front of her and she feels as though her mind is deceiving her. Her constant thoughts about his unfortunate fate prevent her from distinguishing the dream from reality and in the end she sees his body on their bedroom floor and feels his ribs under her fingers as though she is looking for a hole.

Novakovich's stories inspire questioning about the absurdity of war: what is infidelity, where is the line between 
lust, love and hate, as well as how much a person is determined by the soil where s/he comes from and brings with when migrating to other places.

In their houses of fiction Pištalo and Novakovich negotiate their own space with the spaces which they inhabit in the "world", mainly through the tropes of cultural hybridity and identity quest. Their narrations about "home" ironically chart various other locations of the "dislocated world" in which Vladimir Pištalo reasserts the power of fiction when he symbolically addresses the space of discourse, "I will let you have the truth, I will only keep the metaphor" (Pištalo, 2011, p. 92).

\section{References}

Bachelard, G. (1994). The Poetics of Space. Trans. Maria Jolas. Boston, Massachusetts: Beacon Press.

Bakhtin, M.M. (1984). Rabelais and his World, Trans. H. Iswolsky, Bloomington: Indiana University Press.

Bhabha, H. (1992). The World and the Home. Social Text, 31/32, Third World and Post-Colonial Issues, 141-153.

Benjamin, W. (1997). A Berlin Chronicle. In One-Way-Street and Other Writings. Trans. Edmund Jephcott and Kingsley Shorter. London: Verso, 293-346.

Hartog, F. (1988). The Mirror of Herodotus: the Representation of the Other in the Writing of History, Berkeley and Los Angeles: University of California Press.

Novakovich, J. (2012). Shopping for a better country. Essays. Westland. Dzanc Books.

Novakovich, J. (2005). Infidelities. Stories of War and Lust. New York. Harper Perennial.

Pištalo, V. (2009). Milenijum u Beogradu (Millennium in Belgrade). Zrenjanin: Agora.

Pištalo, V. (2011). Venecija (Venice). Zrenjanin: Agora.

Turchi, P. (2004). The Maps of the Imagination: The Writer as Cartographer. San Antonio, Texas: Trinity University Press. 